\title{
BAHASA IKLAN DAN PEMBERDAYAAN PEREMPUAN: SEBUAH KAJIAN KOMUNIKASI DAN BAHASA TERHADAP IKLAN TV PRODUK "CITRA"
}

\author{
The Language of Advertising and Woman Empowerment: \\ A Study of Communication and Language on "Citra" TV Commercial
}

\author{
Katharina Endriati Sukamto dan Dorien Kartikawangi \\ Unika Atma Jaya, Jakarta
}

\begin{abstract}
Abstrak
Memasarkan sebuah produk di media massa bertujuan untuk mencapai target penjualan produk tersebut. Di media televisi, pemasaran ini dilakukan melalui tayangan audio-visual yang biasanya mencakup narasi lisan dan visualisasi. Untuk memasarkan sebuah produk kecantikan, misalnya, umumnya ada alur cerita yang secara visual memamerkan kecantikan perempuan yang menggunakan produk kecantikan tersebut. Secara bersamaan, pemirsa dapat mendengar narasi atau membaca tulisan yang menggambarkan alur cerita yang mempromosikan produk tersebut. Dalam hal ini, bahasa sebagai alat komunikasi dalam iklan memainkan peran yang sangat penting agar dapat mempengaruhi target pemasaran. Makalah ini akan membahas bagaimana produsen "Citra" mengangkat tema pemberdayaan perempuan Indonesia dengan mengkomunikasikan produk kecantikannya melalui bahasa iklan. Melalui pendekatan semiotika (de Saussure, 1966), makalah ini akan mengkaji lima buah iklan TV produk "Citra". Lewat tanda-tanda bahasa yang dikomunikasikan dalam iklan ini, ada makna penting yang ingin disampaikan, yaitu bahwa perempuan Indonesia yang beraktivitas dan berdayaguna (penanda) dapat tetap tampil cantik mempesona berkat produk alami asli dari Indonesia (petanda).
\end{abstract}

Kata kunci: pemberdayaan wanita, tanda, penanda, petanda.

\begin{abstract}
Marketing a product in the mass media deals with how to achieve a sales target. It can be done through audio-visual representations on TV commercials. In marketing a beauty product, for example, commercials featuring beautiful and sexy women are often used to enhance product appeal. At the same time, the visualization is combined with a narrative story or text that is designed to have a persuasive effect on the product. In this case, language plays an important role as it is used as a means to influence the target market. This paper will discuss how the "Citra" producer can introduce the theme of woman empowerment by marketing its products on TV screens. By using the semiotic approach (de Saussure, 1966), this paper will focus on five TV commercials of "Citra." The message being conveyed through the signs is: Indonesian women who are doing activities (signifier) look beautiful and fresh because they use a natural product from Indonesia (signified).
\end{abstract}

Keywords: woman empowerment, sign, signifier, signified.

Ranah, Volume 1, Nomor 2, Desember 2012 | 1 


\section{Pendahuluan}

Iklan merupakan salah satu alat promosi yang banyak digunakan oleh produsen untuk mengkomunikasikan produk yang ditawarkan. Seiring dengan perkembangan teknologi dan ketatnya persaingan, saat ini iklan dikemas dengan semakin kreatif untuk dapat menarik perhatian calon konsumen. Biasanya produsen iklan membuat suatu tema untuk berbagai jenis media masa yang digunakan, baik untuk media audio (radio), visual (cetak), maupun audio-visual (televisi dan internet).

Sementara itu, sebagaimana kita ketahui, media massa sebagai alat komunikasi yang menjangkau masyarakat secara luas memiliki fungsi ganda, yaitu fungsi sosial dan fungsi individu. Fungsi sosial yang diperankan mencakup empat hal, yaitu: 1) pengawasan lingkungan, 2) korelasi antarbagian dalam masyarakat untuk menanggapi lingkungannya, 3) sosialisasi atau pewarisan nilai, dan 4) fungsi hiburan. Fungsi individu yang dijalankannya meliputi: 1) pengawasan atau pencarian informasi, 2) pengembangan konsep diri, 3) fasilitator dalam hubungan sosial, 4) substitusi dalam hubungan sosial, 5) sarana untuk melegakan emosi, 6) pelarian dari ketegangan dan keterasingan, dan 7) bagian dari kehidupan rutin atau ritualisasi. Dengan demikian, sejatinya iklan yang disampaikan melalui media massa secara langsung maupun tidak langsung mengandung fungsi-fungsi yang diperankan oleh media massa, khususnya karena isi pesan yang disampaikan dalam iklan tersebut.

Di Indonesia, beriklan melalui televisi dianggap paling efektif mengingat sebagian besar penduduk Indonesia lebih memilih untuk mengonsumsi televisi dibandingkan radio dan media cetak. Hal ini disebabkan televisi memiliki kelebihan dibandingkan media massa lainnya, yaitu kemampuannya menyampaikan pesan secara paket baik audio maupun visual. Bagan di bawah ini menunjukkan bahwa di Indonesia, selain menjadi media yang tertinggi dikonsumsi masyarakat, media televisi juga dikonsumsi oleh masyarakat dari berbagai usia, yaitu dari usia anak-anak hingga dewasa atau tua.

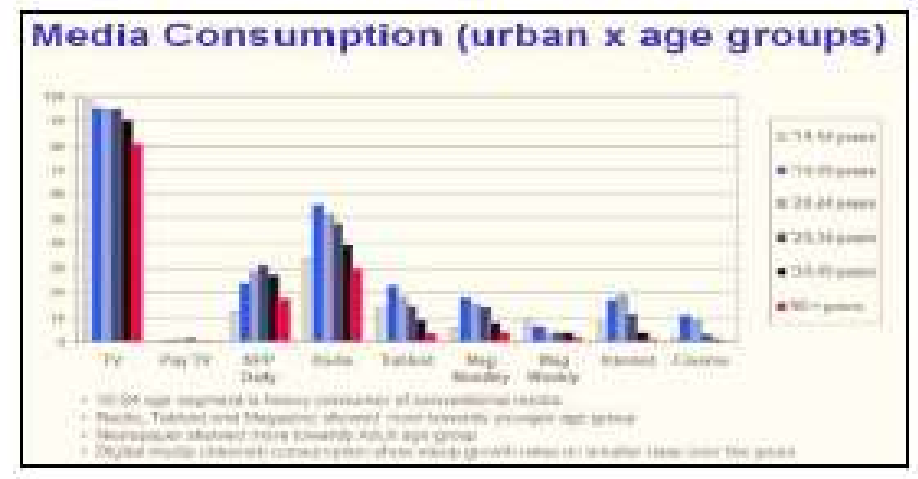

Sumber: Digital Media across Asia

http://comm215.wetpaint.com/page/Indonesia\%3A+Traditional+Media

Iklan di televisi, dalam banyak hal menjadi hiburan bagi pemirsa karena mencakup alur cerita, bintang iklan atau artis yang dipilih, bahasa yang digunakan, musik yang melatarbelakangi alur cerita, maupun visualisasi lain yang melengkapinya dalam satu kemasan penyampaian pesan. 
Dalam perspektif komunikasi pemasaran, iklan banyak dikaji terkait dengan efektifitasnya yang dapat mempengaruhi perilaku pembelian. Kajian tersebut mencakup pesan, media yang digunakan, maupun perilaku konsumennya. Terkait pesan dalam iklan, Stern (1994) mengkaji model komunikasi tentang bagaimana teks disusun dalam iklan. Menurutnya, pesan dalam iklan diperlakukan sebagai teks tertulis. Pesan tersebut merupakan formulasi model komunikasi iklan dari percakapan - tulisan - iklan, serta keterlibatan yang kompleks dari berbagai aspek sumber, pesan dan penerima. Stern (1996) juga mengkaji tentang analisis tekstual dalam paradigma postmodern yang menyajikan pedekatan sistematis untuk memahami makna teks dalam iklan. Tiga tahapan dalam pendekatan sistematis tersebut mencakup: pengidentifikasian elemen-elemen dalam teks, konstruksi makna, dan dekonstruksi (asumsi yang tidak terkatakan). Selain itu, Stern (1996) menyarankan perlunya kontribusi riset perilaku dan budaya dalam mengkaji iklan.

Sementara itu, Hung, Li, dan Belk (2007) mengkaji tentang pemahaman lokal-global atas perempuan modern (new woman) dalam iklan di Cina dengan analisis isi. Kajiannya menyatakan bahwa konsumen dalam ekonomi transisional menerapkan berbagai pendekatan dalam membaca (memahami), termasuk strategi perbedaan budaya dan selfreferencing, untuk menyerap citra ke dalam budaya dan skema konsumsinya.

Dalam perspektif bahasa, iklan selalu dikemas dalam bahasa yang bersifat persuasif atau membujuk, yang tujuannya adalah mempengaruhi calon konsumen untuk membeli jasa atau produk yang ditawarkan. Dalam pengamatan Irianto (2007), bahasa iklan yang ditayangkan di berbagai televisi swasta di Indonesia merupakan varian bahasa tersendiri yang berbeda dari bahasa Indonesia yang umum digunakan. Penggunaan campur kode (code mixing), khususnya Bahasa Inggris, sering kali kita temui. Dikatakannya bahwa "bentuk bahasa iklan [...] disengaja oleh pemasang iklan agar iklannya bisa segera dikenali dan masuk di hati penonton televisi" (Irianto, 2007: 52). Bahasa iklan juga dapat dianggap sebagai fenomena kebahasaan yang sarat dengan makna atau interpretasi. Makna atau interpretasi itu dikomunikasikan melalui tanda (Saussure 1996), yang dapat berupa katakata, gambar, isyarat, dan lain-lain.

Selain perspektif komunikasi pemasaran dan bahasa dalam iklan, ada satu hal lagi yang dimanfaatkan oleh produsen iklan TV untuk memikat pemirsanya, yaitu bintang iklan perempuan. Biasanya artis yang cukup terkenal menjadi pilihan produsen iklan. Keindahan fisik, paras yang molek dan ayu, serta gerak yang lemah gemulai dari perempuan dijadikan sarana utama untuk menarik hati pemirsa agar membeli produk yang ditawarkan. Untuk produk kecantikan, sudah barang tentu perempuanlah yang dijadikan objek pemasaran.

Beberapa penelitian yang mengulas citra perempuan dalam iklan TV mengungkapkan bahwa meskipun perempuan menjadi objek sentral dalam pemasaran sebuah produk, ada ketidak-setaraan gender yang ditampilkan di iklan-iklan TV yang cenderung menempatkan perempuan pada posisi yang sub-ordinat (Martadi 2001, Kusumastutie \& Faturochman 2004, Efianingrum 2009). Implikasi dari pencitraan perempuan yang seperti itu seakan semakin menguatkan asumsi yang berkembang di masyarakat bahwa perempuan adalah objek pelengkap yang hanya akrab dengan ranah domestik saja. Gambaran akan perempuan seperti itu menjadi lebih nyata apabila bahasa yang menyertai tayangan tersebut cenderung menempatkan perempuan pada posisi yang sekunder saja. Dengan kata lain, komunikasi pemasaran lewat objek perempuan dan bahasa menjadi kunci sebuah tema pemasaran. 
Di sisi lain, Shabudin \& Aman (2012) melakukan kajian atas 24 iklan kecantikan dalam bahasa Jepang. Dalam penelitian tersebut dikatakan bahwa meskipun iklan-iklan tersebut dibuat di Jepang, dalam bahasa Jepang, dan untuk kalangan domestik di Jepang, ada kecenderungan bahwa di Jepang ideologi kecantikan perempuan masih berkiblat pada kecantikan Oksidental (cenderung kebarat-baratan). Hal ini menunjukkan bahwa meskipun Jepang adalah negara yang maju dan kuat perekonomiannya, namun untuk mengkomunikasikan produknya sendiri Jepang masih tergantung pada ideologi Barat (Shabudin dan Aman, 2012: 813).

Terkait hal di atas, makalah ini akan membahas bagaimana bahasa iklan dapat mengkomunikasikan sisi yang dapat mengangkat citra perempuan Indonesia. Di tengah persaingan yang didominasi oleh produk kecantikan impor, "Citra" - sebagai produk kecantikan lokal-mampu bertahan dan berkembang. Iklan-iklan "Citra" dikemas sedemikian rupa melalui bahasa - baik verbal maupun non-verbal - yang mampu menyampaikan pesan kepada perempuan Indonesia untuk dapat berdayaguna sekaligus tetap memperhatikan kecantikannya. Dengan demikian, fokus dari penelitian ini adalah pada bagaimana produsen produk kecantikan "Citra" mengangkat tema pemberdayaan perempuan Indonesia melalui bahasa iklan di televisi dan mengkomunikasikan hal ini kepada pemirsanya.

\section{Teori dan Metodologi}

Kajian yang menggunakan paradigma konstruktivis ini berlandaskan pada teori dan metode analisis teks dari Ferdinand de Saussure (1966), bapak semiotika, tentang bagaimana menginterpretasikan tanda (sign). Berdasarkan teorinya, tanda terdiri dari suara (sounds) dan gambar (image) yang disebutnya sebagai penanda (signifier), serta konsep yang dibawa oleh suara dan gambar ke dalam pikiran yang disebutnya sebagai petanda (signified). Sebagaimana ditulisnya:

I call the combination of a concept and a sound-image a sign, but in current usage the term generally designates only a sound-image, a word [...]. I propose to retain the word sign (signe) to designate the whole and to replace concept and soundimage respectively by signified and signifier; the last two terms have the advantage of indicating the opposition that separates them from each other and from the whole of which they are parts. As regards sign, if I am satisfied with it, this is simply because I do not know of any word to replace it, the ordinary language suggesting no other (Saussure, 1966: 67).

Dalam ilmu semiotika, kata-kata atau bentuk verbal adalah tanda. Demikian juga halnya dengan bentuk non-verbal, yang dapat berupa gerakan, simbol, isyarat, atau gambar. Melalui interpretasi atas tanda sebagai landasan dalam ilmu semiotika, kita dapat menganalisis dan memahami makna bahasa (simbol dan tanda) dalam iklan, foto, bangunan, film, dan lain sebagainya (Berger, 2000). Seperti yang dikemukakan oleh Myers (2008), penelitian yang menggunakan pendekatan semiotika tidak mengkaji tanda secara terpisah, melainkan bagaimana kita memahami hubungan antara tanda dan simbol.

Iklan "Citra" dapat kita lihat di berbagai stasiun televisi setiap hari. Iklan tersebut berganti tema setiap periode tertentu sesuai kebijakan perusahaan. Penelitian ini tidak menetapkan pilihan iklan yang dikaji berdasarkan tema, melainkan berdasarkan generasi yang menjadi sasaran iklan. Kajian ini menganalisis teks dalam lima iklan "Citra" yang terdiri dari awal mula Citra, Citra untuk remaja, Citra untuk dewasa muda, dan Citra untuk dewasa. 


\section{Hasil dan Pembahasan}

\section{Pencitraan Perempuan dalam Iklan}

Dalam industri periklanan, perempuan sering kali dimanfaatkan sebagai bintang iklan untuk memasarkan berbagai produk. Demi kepentingan pasar, perempuan seksi acap kali dijadikan objek iklan yang harus tampil memikat hati pemirsa. Lekuk tubuh, gerakan, serta suara perempuan diekspresikan sedemikian rupa sehingga citra perempuan cenderung menempati posisi yang sekunder dan lemah.

Di samping tampilan fisik, tak jarang jalan cerita, visual pendukung, musik, dan teks memberikan gambaran tentang hedonisme terhadap perempuan. Salah satu contoh iklan yang pernah ramai diperbincangkan adalah iklan salah satu provider telepon selular yang mempromosikan harga Rp 1,- per detik untuk menelepon. Dalam iklan itu, provider tersebut menggunakan bintang iklan perempuan yang memakai kaus bertuliskan Rp. 1,-/ detik. Visualisasi tersebut kemudian dimaknai bahwa perempuan tersebut berharga Rp. 1,-/detik. Iklan tersebut akhirnya ditarik dari peredaran karena menuai kritik keras dari berbagai kalangan. Iklan lain yang mengalami nasib serupa adalah iklan pakaian dalam laki-laki. Dalam iklan tersebut, divisualisasikan seorang laki-laki yang sedang berenang dan pakaian dalamnya diambil seorang perempuan cantik dan seksi. Alur cerita ini seperti cerita rakyat "Jaka Tarub" dengan peran yang dibalik ${ }^{1}$. Ditimpali suara merdu "(sebut merk) ... idaman wanita", citra perempuan yang negatif semakin diteguhkan dalam iklan tersebut. Baru beberapa hari tayang, iklan itu harus ditarik dari peredaran karena dianggap tidak etis dan merendahkan martabat perempuan.

Dalam pengamatan Pranata (2001: 161), perhatian pemirsa iklan seringkali "terjebak dalam bad taste advertising," sehingga "sense of aesthetics digantikan oleh estetisisme." Dengan kata lain, demi sebuah tujuan konsumerisme, tubuh perempuan dieksploitasi sedemikian rupa sehingga daya tarik seksual perempuan dimanfaatkan untuk menyampaikan pesan "belilah produk ini."

Contoh-contoh di atas dan juga kajian-kajian sebelumnya menunjukkan bagaimana sebenarnya pencitraan perempuan dilakukan melalui iklan. Perempuan dipandang sebagai makluk yang lemah, tetapi sekaligus juga sebagai penggoda. la hanya layak bekerja dalam konteks domestik dengan segala kerepotannya, misalnya dalam iklan sabun, bumbu masak, pembersih rumah tangga, dan hal-hal lain yang terkait dengan rumah tangga.

\section{Iklan "Citra" dan Pemberdayaan Perempuan}

Sebenarnya, iklan dapat menggunakan perempuan sebagai bintang untuk berbagai produk tanpa harus meletakkannya dalam posisi yang lemah dari berbagai sudut pandang. Salah satu produk yang menggunakan tema pemberdayaan perempuan dalam iklannya adalah produk kecantikan "Citra".

Kelima iklan Citra yang menjadi data penelitian ini mengambil objek perempuan. Dalam iklan-iklan yang menonjolkan kecantikan perempuan, pesan yang sering disampaikan adalah perempuan yang memiliki kulit yang putih, halus, lembut, dan segar. Konsep iklan

1 Dalam cerita "Jaka Tarub", dikisahkan bahwa Jaka Tarub mencuri selendang seorang bidadari - Dewi Nawangwulan - yang tengah turun ke bumi dan mandi di sebuah telaga. Akibatnya, Dewi Nawangwulan tidak dapat kembali ke kahyangan dan akhirnya diperisteri oleh Jaka Tarub. 
seperti ini menggambarkan bahwa perempuan digambarkan untuk menjadi sosok yang selalu ingin tampil memikat dan menarik.

Sebagaimana telah dipaparkan di atas, berdasarkan teori Saussure, tanda yang dikaji dalam penelitian ini mencakup narasi, alur cerita, dan visualisasi. Narasi disajikan dalam bentuk transkrip, sedangkan alur cerita dan visualisasi dideskripsikan secara ringkas untuk memberikan gambaran keseluruhan isi pesan dalam iklan. Secara berturut-turut, berikut ini disajikan iklan mulai dari awal mula Citra (Iklan 1), Citra untuk remaja (Iklan 2), Citra untuk dewasa muda (Iklan 3 dan 4), dan Citra untuk dewasa (Iklan 5).

\section{Iklan 1: Awal mula Citra}

Narasi:

Pada awalnya... Citra... Seni bagi nusa, negeri pertiwi... Junjung tradisi, dan budaya... Karena kekuatan suatu bangsa... berawal... dari perempuan... Dari Citra, untuk perempuan Indonesia.

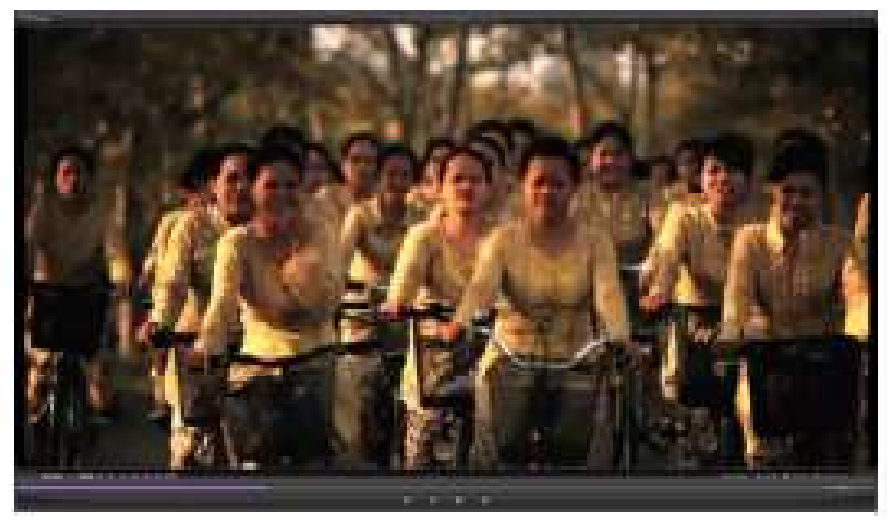

Visualisasi dan alur cerita:

Perempuan Indonesia, berjalan dari satu persitiwa ke peristiwa berikutnya yang menggambarkan berbagai aktivitas perempuan Indonesia, dengan berbagai ragam budaya yang melatar belakangi. Disela-sela perjalanannya, perempuan tersebut diilustrasikan melakukan perawatan kulit.

\section{Iklan 2: Citra untuk remaja}

Narasi:

Pria 1 : Man, tolong jemput adik gue dong.

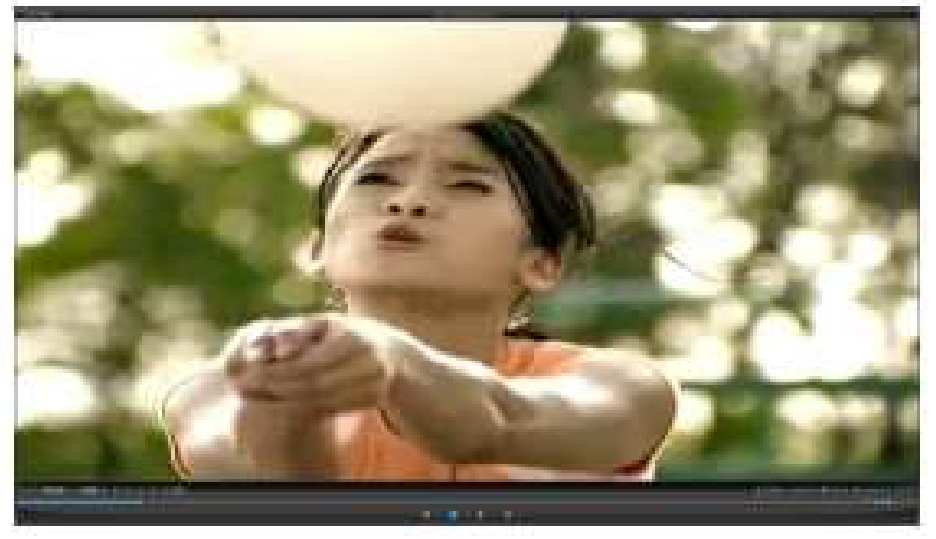


Pria 2 : Si Brownies?

Pria 1 : Iya, si Acha.

Narasi : Persembahan baru dari Citra... sabun Citra. Dengan bengkoang, formula yang telah dipercaya, menjadikan kulit putihmu bersinar.

Pria 2 : Acha!

Narasi : Baru, sabun Citra, persembahan untukmu perempuan Indonesia.

Visualisasi dan alur cerita

Seorang laki-laki muda meminta tolong temannya untuk menjemput adiknya (Acha, penyanyi) yang sedang bermain voli di tengah terik matahari. Teman kakak ini menyebut Acha dengan panggilan 'si Brownies'. Dia tidak tahu bahwa Acha telah menggunakan sabun Citra yang mengandung ekstrak bengkoang sehingga kulitnya menjadi putih. Karenanya, sesampainya dia di tempat aktivitas Acha dia sempat salah panggil ketika melihat perempuan mirip Acha yang berkulit coklat.

\section{Iklan 3: Citra untuk dewasa muda}

Narasi:

Perempuan 1 : Tu wa ga.

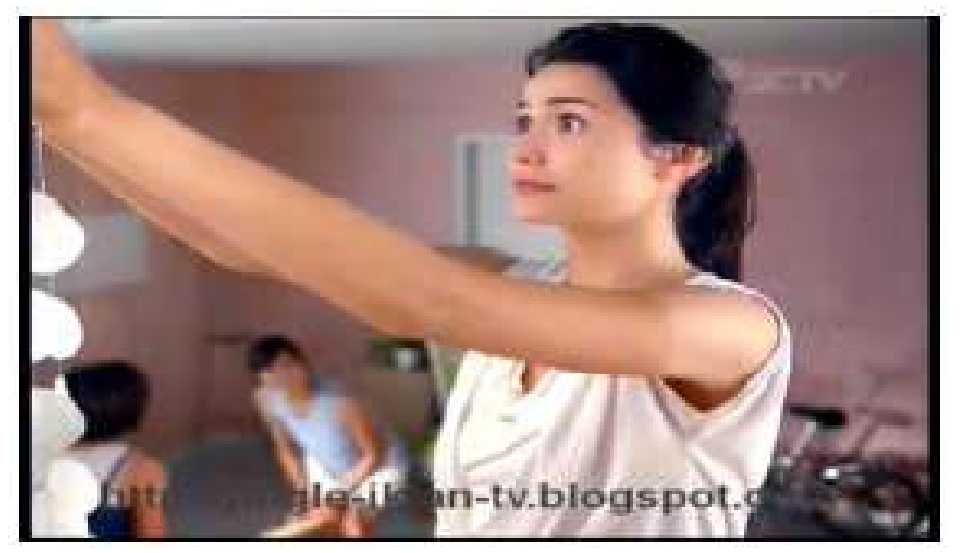

Perempuan $1 \& 2:=$ ugh

Perempuan $3:=$ ugh

Perempuan 1 : Selamat tinggal asrama.

Perempuan 2 : Ups ...

Perempuan $1:$ Ah ...

Perempuan 3 : Hah?

Perempuan 2 : Hehe... Temboknya kayak kulit kamu. Hehe...

Perempuan 1 : Huuuh..

Perempuan 3 : Pakai Citra ke seluruh tubuhmu, ya.

Narasi : Citra lasting white UV dengan ekstrak bengkoang alami dan vitamin. Jadikan kulitmu tampak putih dan merata di seluruh tubuh dan 
Bahasa Iklan dan Pemberdayaan .....

melindunginya dari sinar matahari.

Perempuan 2 : Kulit putih baru...

Perempuan 3 :...dan penggemar baru juga

Narasi : Citra baru! Halo, kulit tampak putih merata.

Visualisasi dan alur cerita

Seorang perempuan bersama teman-temannya sedang merapikan kamar asrama untuk pindah ke rumahnya sendiri. Ketika mengangkat lukisan maupun barang di ruangan tersebut tampak warna tembok yang berbeda-beda. Perbedaan warna tembok tersebut dikatakan oleh temannya sebagai sama dengan warna kulitnya yang tidak rata. Oleh teman-temannya dia diingatkan untuk memakai Citra lasting white UV yang membuat warna kulitnya rata.

\section{Iklan 4: Citra untuk dewasa muda}

Narasi:

Sinar matahari mengubah segalanya... Karena itu rawatlah kulit tubuhmu... Baru, Citra lasting

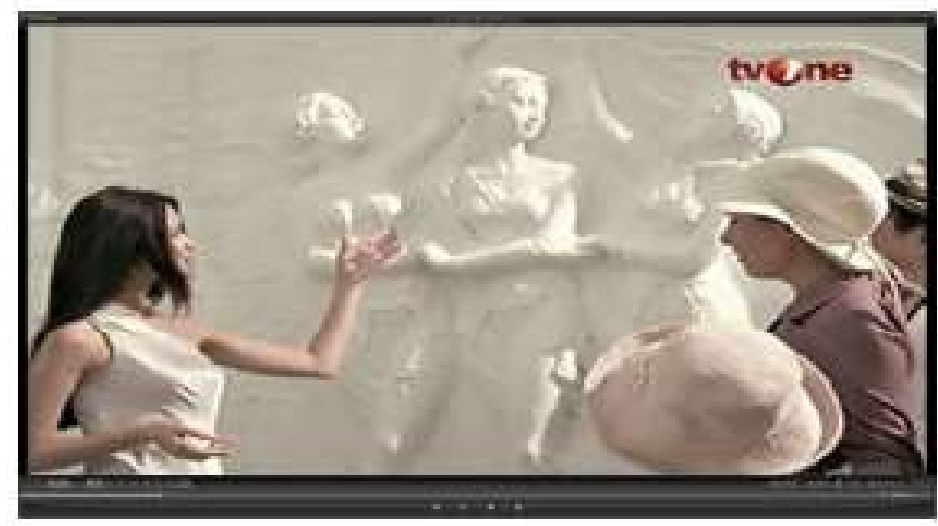

white lotion dengan bengkoang dan double sunscreen untuk kulit putihmu senantiasa tampak putih... Citra lasting white lotion.

Visualisasi dan alur cerita

Seorang perempuan sedang beraktivitas di tengah terik matahari setiap hari. Digambarkan bahwa terkena sinar matahari terus menerus setiap hari akan merusak kulit. Namun demikian perempuan ini dapat menjaga kecantikan kulitnya dengan Citra lotion.

Iklan 5: Citra untuk dewasa

Narasi: 
Pria: Vita, kecintaan Indonesia. Banyak yang mengagumi pesonanya, cantiknya.

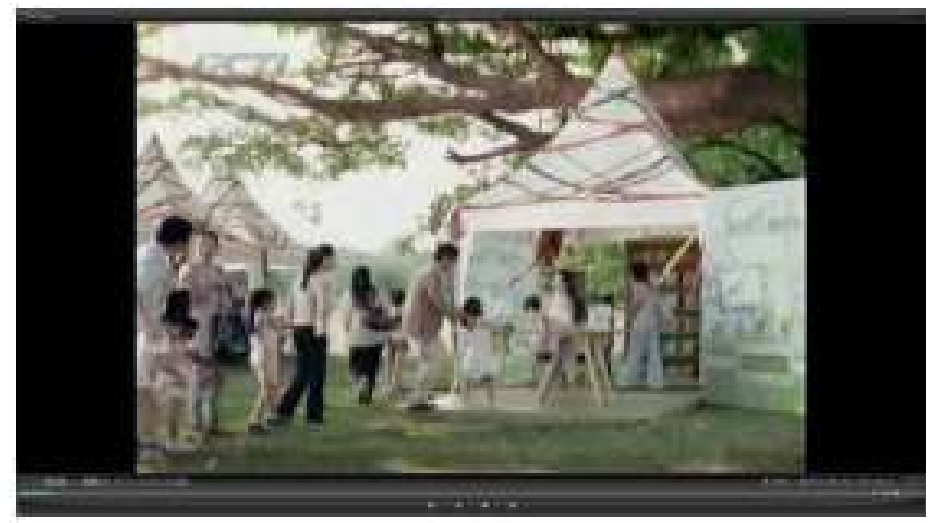

Di mataku bahkan lebih cantik dari yang mereka kenal.

Perempuan : Kurawat kulitku dari yang mudah kulihat hingga yang sulit kulihat, seluruhnya.

Pria: Bangganya, menyebut dirinya istriku.

Perempuan : Citra...

Visualisasi dan alur cerita:

Vita, seorang perempuan aktif dan terkenal, yang juga seorang istri, digambarkan sedang melakukan beberapa aktivitas: menandatangani buku (karyanya) dan menghadiri sebuah acara televisi (bintang tamu). Ditengah kesibukannya dia tetap merawat kecantikan kulitnya dengan Citra body lotion. Pada bagian akhir, di samping kalimat suaminya yang menyatakan bangga ketika disebutkan sebagai istrinya, juga ditutup dengan tagline 'cantik seutuhnya.'

Kelima iklan yang telah disebutkan di atas menggunakan objek perempuan sebagai bintang iklan. Narasi yang diperdengarkan semuanya menggambarkan perempuan beraktivitas yang tetap dapat tampil cantik menawan karena menggunakan produk kecantikan Citra buatan Indonesia dengan bahan alami yang berasal dari Indonesia, yaitu buah bengkoang.

Dari analisis semiotika terhadap lima iklan Citra dapat diperoleh gambaran sebagai berikut:

\section{Penanda: Perempuan dan aktivitasnya}

Sosok perempuan yang ditampilkan pada iklan pertama (awal mula Citra) adalah perempuan Indonesia dari berbagai usia, dari usia belia hingga tua. Unsur tradisi budaya tanah air cukup menonjol dalam iklan ini, yang digambarkan dengan perempuan berkebaya yang sedang membatik, menenun, bersepeda, dan menari. Ada pula perempuan Bali yang sedang membawa sesaji di kepalanya.

Pada iklan yang kedua (Citra untuk remaja), perempuan Indonesia yang ditampilkan berusia belia dengan aktivitas bermain voli di lapangan terbuka. Pesan yang ingin disampaikan dalam iklan ini adalah kegiatan olah raga seperti ini dapat membuat kulit perempuan menjadi gelap, kotor, berkeringat, dan tidak bersinar.

Iklan yang ketiga, yaitu Citra untuk dewasa muda, menampilkan sosok perempuan yang sedang mengemasi barang-barangnya di asrama karena akan pindah ke tempat lain. Gambaran perempuan yang ditonjolkan dalam iklan ini adalah perempuan 
yang aktif di luar rumah yang ditandai dengan sebagian kulit di lengan yang terbakar matahari.

Pada iklan yang keempat, Citra untuk dewasa muda, perempuan yang ditampilkan adalah perempuan aktif yang beraktivitas di luar rumah di tengah terik matahari.

Iklan yang kelima, yaitu Citra untuk dewasa, menggambarkan sosok perempuan dewasa yang telah menikah dan menjadi terkenal karena karya-karyanya. Perempuan tersebut (Vita) digambarkan sibuk menghadiri sebuah acara. Suaminya dengan bangga menyaksikan istrinya dalam acara tersebut.

\section{Petanda: Kecantikan perempuan aktif}

Kelima iklan Citra yang menggunakan objek perempuan sebagai penanda memberikan petanda kecantikan perempuan aktif mulai dari usia remaja hingga dewasa. Bagaimana produsen produk kecantikan "Citra" mengangkat tema pemberdayaan perempuan melalui bahasa iklan di televisi tentu dapat kita lihat dari alur cerita, narasi dan visualisasi yang digunakan. Kelima iklan "Citra" yang menjadi bahan kajian dalam tulisan ini menampilkan perempuan yang aktif baik di dalam rumah maupun di luar rumah. Sebagai produk lokal yang menggunakan bengkoang, buah asli Indonesia sebagai sari pemutih dan pembersih kulit, "Citra" mengaitkannya dengan aktivitas tradisional maupun modern dari perempuan Indonesia. Melengkapi aktivitas tersebut, sebagaimana telah dipaparkan sebelumnya, perempuan dalam iklan "Citra" juga merawat dirinya. Hal ini di beberapa iklan 'Citra" dinyatakan sebagai 'cantik seutuhnya', yang dapat dimaknai sebagai cantik luar dan dalam, baik fisik (cantik bagian luar meskipun beraktivitas) maupun kepribadian (cantik bagian dalam).

Kelima iklan yang dijadikan data penelitian ini menonjolkan beberapa tanda yang membawa makna. Penanda (signifier) dan petanda (signified) akan membentuk satu kesatuan yang disebut dengan tanda kebahasaan. Penanda dapat berupa suara atau tulisan (verbal) atau juga gambar atau gerakan (visual atau non-verbal) yang mengandung makna, sedangkan petanda merupakan konsep atau gambaran yang ada dalam pikiran kita.

Dalam iklan Citra yang mengangkat tema kecantikan, secara umum dapat disebutkan bahwa penandanya adalah perempuan dan aktivitas yang dilakukannya, dan petandanya adalah kecantikan perempuan aktif dari usia remaja hingga dewasa. Tanda, yang merupakan kesatuan antara penanda dan petanda, adalah perempuan aktif yang tetap dapat menampilkan kecantikannya karena menggunakan produk kecantikan Citra yang ditawarkan, yang dalam hal ini dapat berupa pelembab (Iotion), sabun, atau alat kecantikan lainnya.

Pada saat pesan iklan ini disampaikan, sejumlah penanda visual yang ditampilkan menunjukkan berbagai aktivitas perempuan, mulai dari kegiatan domestik hingga kegiatan di luar rumah. Kegiatan yang dilakukan ada yang sifatnya tradisional seperti membatik, memasak, dan menari, tetapi ada juga yang modern seperti bermain voli dan bekerja di luar rumah.

Seperti yang telah disebutkan sebelumnya, komunikasi pemasaran lewat objek perempuan dan bahasa menjadi kunci sebuah tema pemasaran. Kusumastutie dan Faturochman (2004) menyatakan bahwa banyak iklan televisi menempatkan perempuan 
pada posisi yang subordinat, di mana citra kecantikan sengaja ditonjolkan untuk memenuhi kebutuhan laki-laki. Sejalan dengan ihwal kesetaraan gender yang telah seringkali didengungkan, kesadaran para pembuat iklan akan hal ini mulai meningkat. Meskipun secara kodrati peran laki-laki dan perempuan tidaklah sama, dalam hal-hal tertentu laki-laki dan perempuan berada pada kedudukan yang sejajar dan mereka mempunyai hak serta kesempatan yang sama. Pekerjaan yang dahulu didominasi oleh laki-laki, seperti misalnya dokter, pengusaha, dan lain-lain, sekarang ini telah banyak dirambah oleh perempuan.

Iklan "Citra" telah mampu menjadi pembeda dengan produk kecantikan lainnya yang sejenis. Produk lain yang sebagian besar adalah produk import - seperti misalnya Pond's, Sinzhui, dan Biore - umumnya mengangkat tema bahwa kecantikan indentik dengan kulit yang putih. Yang membedakan "Citra" dengan produk-produk itu adalah "Citra" tidak mengatakan kulit yang 'putih' melainkan 'bersih' karena menggunakan produk alam sari bengkoang. Dengan demikian dapat dikatakan bahwa penanda dan petanda yang digunakan dalam strategi dan implementasi iklan "Citra" mampu dengan baik menggambarkan pemberdayaan perempuan dalam keseluruhan makna iklan.

Dalam paparan tentang fungsi media, dijelaskan tentang fungsi sosial dan individual yang dijalankan oleh media. Jika dikaji lebih lanjut berdasarkan modelling theory (Defleur \& Dennis, 2009), maka apa yang disajikan dalam iklan "Citra" dapat diadopsi dan menjadi model perilaku yang positif bagi perempuan Indonesia. Secara sederhana proses modelling diawali ketika seseorang melihat bentuk tindakan yang dilakukan oleh pemeran iklan. Selanjutnya penonton tersebut mengidentikkan dirinya dengan pemeran iklan tersebut dan menirukan apa yang dilakukan pemeran. Jika yang disajikan adalah hal yang bersifat positif, maka hal positif itulah yang akan ditiru dan dikerjakan oleh penontonnya. Dengan demikian, dengan strategi dan implementasi iklan yang mengangkat tema 'perempuan yang berdaya', maka sejatinya iklan "Citra" ini ikut serta mengangkat 'pemberdayaan perempuan', khususnya perempuan Indonesia, melalui produk Indonesia yang dinyatakan sebagai menggunakan resep warisan budaya Indonesia, yaitu bersih dengan sari bengkoang namun dapat tetap melakukan berbagai aktivitas baik yang bersifat domestik maupun non-domestik.

Selanjutnya, ketika makna dikaitkan dengan simbol bahasa (language symbol) atau pola simbol (pattern of symbol), sebenarnya penangkapan makna tersebut didasarkan oleh interpretasi personal yang tentunya sangat dipengaruhi oleh luasnya pengalaman dan kerangka referensi pemirsanya. Makna individual tersebut akan dibagikan dengan orang lain dalam perbincangan antar pribadi maupun dalam kelompok sehingga menjadi makna bersama yang meluas. Hal ini berlangsung berulang-ulang dan membawa pemirsa pada perilaku positif tentang bagaimana seharusnya 'menjadi perempuan yang cantik seutuhnya'. Ketika hal ini terjadi, apakah mereka menggunakan produk "Citra" atau tidak, yang tampak menonjol adalah pemberdayaan perempuan, yaitu perempuan yang memiliki aktivitas dan produkif (baca: cantik dalam kepribadian, intelektual dan perilaku), serta tetap cantik secara fisik. 


\section{Simpulan dan Saran}

Iklan Citra menawarkan produk kecantikan wanita dengan strategi yang berbeda, yaitu menampilkan sosok perempuan yang aktif (beraktivitas di dalam maupun di luar rumah), tetapi dapat tetap tampil cantik dan menarik. Ditinjau dari pendekatan semiotika, yaitu kajian yang mencari hubungan antara penanda dan petanda, iklan ini telah menyampaikan pesan bahwa perempuan Indonesia tidak harus menempati posisi subordinat di masyarakat. Iklan Citra mampu menghadirkan sosok perempuan Indonesia dari usia remaja hingga dewasa yang aktif bekerja dan berolah raga di luar rumah namun mereka dapat tetap menampilkan daya tarik mereka sebagai perempuan yang cantik, anggun, dan menarik berkat produk kecantikan alami buatan Indonesia.

Dari segi budaya, iklan Citra berhasil menonjolkan nilai-nilai ketimuran perempuan Indonesia. Strategi yang digunakan adalah mengangkat tema perempuan Indonesia yang aktif dan berdayaguna, namun tetap dapat tampil cantik dan mempesona. Tema perempuan yang berdayaguna tersebut diimplementasikan melalui visualisasi, alur cerita, dan narasi sebagai penanda. Adapun petanda yang dapat dimaknai bahwa perempuan yang berdaya itu adalah aktif dan produktif (cantik dari dalam), tetapi dapat dan harus merawat kecantikan fisiknya (cantik dari luar). Tag line 'cantik seutuhnya' menggambarkan hal ini.

Tema perempuan yang aktif dan berdayaguna ini, seiring dengan fungsi media masa, selanjutnya dapat menjadi inspirasi bagi perempuan Indonesia yang menonton iklan tersebut, untuk memiliki makna interpersonal, dan menjadi makna bersama dalam kelompok maupun lingkungannya. Dengan demikian, iklan "Citra" dapat menjadi alat pemberdayaan perempuan.

Penelitian lanjutan yang mempertemukan bidang kebahasaan dan bidang komunikasi pemasaran untuk iklan-iklan dengan tema yang serupa maupun berbeda seyogyanya dapat terus dilakukan agar para produsen iklan dapat lebih memperhatikan bahasa - baik verbal maupun non-verbal - yang digunakan. Sebagaimana disampaikan oleh Saussure (1966: 77), bahasa adalah "institusi sosial"; oleh karena itu para produsen iklan perlu memahami dampak yang akan tercipta akibat makna yang ditimbulkan oleh iklan. 


\section{Daftar Pustaka}

Berger, Arthur A. 2010. Media and Communication research Methods: An Introduction to Qualitative and Quantitative Approaches. 2nd ed, Thousand Oaks: Sage Publication, Inc.

Defleur, Melvin L. dan Everette Dennis. 2009. Understanding Mass Communication, 7th ed, Boston: Houghton Mifflin Harcourt ( $\mathrm{HMH})$.

Efianingrum, Ariefa. 2009. "Citra Perempuan dalam Iklan di Televisi," Jurnal Penelitian Humaniora, Vol. 14(1), April 2009, hlm. 1-18.

Hung, Kineta H., Stella Yiyan Li \& Russell W. Belk. 2007. "Glocal Understandings: Female Readers' Perception of the New Woman in Chinese Advertising," Journal of International Business Studies, Vol. 30(6), hlm. 1034-1051.

Irianto, Sugeng. 2007. "Bahasa Iklan Televisi Indonesia," Ragam, Vol. 7(1), April 2007, hlm. 42-59.

Istanto, Freddy H. 2000. "Rajutan Semiotika untuk Sebuah Iklan: Studi Kasus Iklan Long Beach," Nirmana, Vol. 2(2), Juli 2000, hlm. 113-127.

Kusumastutie, Naomi Srie dan Faturochman. 2004. "Analisis Gender pada Iklan Televisi dengan Metode Semiotika," Jurnal Psikologi, No. 2, hlm. 130-141.

Martadi. 2001. "Citra Perempuan dalam Iklan di Majalah Femina Edisi Tahun 1999: Kajian Semiotik terhadap Nilai-nilai Gender dalam Desain Iklan," Nirmana, Vol. 3(2), Juli 2001, hlm. 135-157.

Myers, Michael D. 2008. Qualitative Research in Business \& Management. London: Sage Publications, Ltd.

Pranata, Moeljadi. 2001. "Estetisisme dan Dilema Pemberdayaan Perempuan dalam Iklan," Nirmana, Vol. 3(2), Juli 2001, hlm. 158-165.

Saussure, de Ferdinand. 1966. Course in General Linguistics. Edited by Charles Bally \& Albert Sechehaye. New York: McGraw Hill.

Shabudin, Maserah dan Idris Aman. 2012. "Wacana dan Ideologi Iklan Produk Kecantikan Berbahasa Jepun," GEMA Online ${ }^{\mathrm{TM}}$ Journal of Language Studies, Vol. 12(3), Special Section, September 2012, hlm. 789-816.

Stern, Barbara B. 1994. "A Revised Communication Model for Advertising: Multiple Dimensions of the Source, the Message, and the Recipient," Journal of Advertising, Vol. 23(2), hlm 5-15.

Stern, Barbara B. 1996. "Textual Analysis in Advertising Research: Construction and Deconstruction of Meaning," Journal of Advertising, Vol. 25(3), hlm 6173.

\section{Sumber internet:}

Digital Media across Asia, http://comm215.wetpaint.com/page/Indonesia\%3A+ Traditional+Media, diakses 5 Agustus 2012, pukul 16:00. 